\title{
Description of carcass classification goals and the current situation in South Africa
}

\author{
E.C. Webb \\ Department of Animal and Wildlife Sciences, University of Pretoria, Private Bag X20, Hatfield, 0028, \\ Pretoria, South Africa
}

(Received 7 December 2014; Accepted 1 April 2015; First published online 29 July 2015)

\begin{abstract}
Copyright resides with the authors in terms of the Creative Commons Attribution 2.5 South African Licence.
See: http://creativecommons.org/licenses/by/2.5/za

Condition of use: The user may copy, distribute, transmit and adapt the work, but must recognise the authors and the South African Journal of Animal Science.
\end{abstract}

\begin{abstract}
Carcass classification is an essential part of efficient animal production, price fixing and meeting consumer demands. Carcass classification (or grading) is based on the description of carcasses by means of clearly defined characteristics that are of prime importance to the meat industry, retailers and consumers. Significant variation exists in carcass composition and quality due to the effects of species, age, maturity type, sex and interaction effects with animal production systems. A number of extrinsic and intrinsic factors affects carcass and meat quality and the purpose of carcass classification in South Africa is to classify carcasses to ensure more consistent meat quality, composition and consumer satisfaction. Although carcass inspection is compulsory in South Africa, carcass classification is not a requisite at all South African abattoirs. South Africa employed a carcass grading system from 1944 to 1992, which was replaced by a carcass classification system in 1992. Carcass classification differs fundamentally from carcass grading. In carcass classification there is a shift of emphasis to classifying carcasses in order to provide the meat industry and consumers with a choice of different types of carcasses in terms of carcass composition and physical attributes, while there is no indication of perceived quality as is provided in a grading system. In a carcass grading system, an indication is provided of standard, prime and superior carcass grades which relate to standard, prime and superior meat quality. The conceptual basis of the carcass classification system is therefore based on the principle that producers, retailers and consumers differ in terms of their perceptions and expectations of carcass and meat quality, and subsequent eating experience. More recently it has become apparent that the current classification system is being used as a grading system due to the use of preferred classes, which defeats the original purpose of a classification system. Furthermore, recent research suggests that the variation within carcass classification categories has increased considerably due to differences between livestock breeds and types, animal production systems and the use of modern feedstuffs and growth enhancing technologies. The purpose of this paper is to review the characteristics and goals of the current South African carcass classification system, grading systems in other countries and the implications for effective marketing, price fixing and consumer satisfaction based on the complex cycle from 'farm to fork'.
\end{abstract}

\footnotetext{
Keywords: Carcass classification, carcass grading, beef, sheep, marketing, consumer acceptance

\#Corresponding author: Edward.webb@up.ac.za
}

\section{Introduction}

Carcass classification is an essential part of efficient animal production, meat price determination and meeting consumer demands. Carcass classification or grading is based on the description of carcasses by means of clearly defined characteristics that are of prime importance to the meat industry and consumers (Kempster et al., 1982). These authors also highlighted the importance of aligning the biological and agricultural aspects of livestock production with marketing considerations, to meet changing market demands. Significant variation exists in carcass composition and quality due to the effects of species, age, maturity type, sex and interaction effects with production systems and technologies (Webb \& Erasmus, 2013). A number of extrinsic and intrinsic factors affect the composition and quality of carcasses, with subsequent effects on meat quality (Viljoen et al., 2002; Webb \& Erasmus, 2013). The purpose of carcass classification is to classify carcasses based on clearly defined quality attributes to ensure more consistent meat quality and consumer satisfaction. This means that carcasses of similar composition and quality are classified in the same category to reduce the variation between carcasses and ensure more consistent end products. 
The Meat Safety Act (Act 40 of 2000) provides guidelines for the conversion of livestock to meat, to ensure a safe and wholesome product for consumers, while the Agricultural Product Standards Act (Act 119 of 1990) helps to control and set specific product standards for local and export purposes by means of inspection, classification or grading (by distinctive marks) and sampling for quality control. Producers, retailers and consumers differ in terms of their perceptions and expectations regarding carcass and meat quality, as well as the eating experience. It has been established that consumers in the same country do not necessarily prefer the same products, which highlights the importance of market segmentation (Oliver et al., 2006), as well as the provision of a choice of products with different physical and sensorial characteristics. In the case of meat, this can be managed by means of an effective classification or grading system.

Carcass inspection is compulsory in all abattoirs in South Africa and entails the inspection of carcasses for diseases and defects. Carcasses that are affected with diseases or certain defects are either partially or completely condemned. Carcass inspection is not negotiable in terms of public health and safety. By contrast, carcass classification is not compulsory at all abattoirs and entails a rather intricate system of classifying carcasses according to age, fat code, conformation and sex. These characteristics provide an effective way of classifying carcasses into clearly defined categories based on age, fat code and conformation score, to market meat with specific compositional and quality attributes. The purpose of this paper is to provide a review of the characteristics and goals of the current South African carcass classification system, grading systems in other countries and the implications for effective marketing, price determination and consumer satisfaction based on the complex cycle from 'farm to fork'.

\section{Beef and sheep production systems}

To appreciate the complexities of carcass classification in South Africa, it is important to understand livestock production cycles. Livestock production is based on a system where cattle and sheep are mostly farm-bred and raised. It is estimated that about $70 \%$ of cattle produced by commercial farmers is sold as weaners and fattened intensively in different combinations of feeding systems, ranging from intensive to semi-extensive and grass fattening systems (Webb \& Erasmus, 2013). Many of the grass-fed cattle (ca. $30 \%$ ), which include long weaners or oxen, are sold at a later stage from the veld (pasture) or after a short intensive fattening period. A number of different combinations of production and fattening occurs based on the availability of grazing and current weaner calf and feed prices. In terms of small stock, it is clear that most lambs are fattened on the veld. Livestock production with the emphasis on red meat production entails a complex cycle from 'conception to consumption' or from 'farm to fork' - that requires careful production management and knowledge of product quality and consumer needs (Webb, 2013).

Detailed knowledge of the current South African beef classification system is essential to improve the economic efficiency and ensure competitiveness of the red meat industry. This knowledge is used to adjust livestock breeding policies and production practices to produce carcasses and meat that fetches the best prices and complies with consumer requirements. In the South African red meat industry there are essentially three steps in marketing beef or sheep carcasses, namely carcass inspection, classification and price determination. Kempster et al. (1982) defined classification as the description of carcasses by the characteristics which are of prime importance to meat traders. These characteristics are described separately without attributing relative importance or cash value differences to them. This description is relevant because it highlights the fundamental aspects of carcass classification namely, (a) classification must describe a carcass, (b) the characteristics described must be important to the meat trader, and (c) carcass classification must in no way reflect the economic importance of the carcass, otherwise the trader may be biased in his purchase.

Effective marketing depends on minimum specifications or standards. Since agricultural products can generally not be produced to specifications, they have to be classified or graded. Unfortunately red meat suffers one major drawback, namely that there is too much variation in composition, physical attributes and quality, despite the best intentions to reduce the variation in meat quality. This is problematic because consumers value consistent meat quality.

The response from the meat industry was the introduction of the Red Meat Scheme of 1964 and 1985 - 1992. This scheme made provision for a meat grading system that gave the Meat Board total control, based on the carcass grade and mass. The Meat Board established minimum prices (floor prices) for auctioneering of carcasses. The carcass grades indicated quality and value, which were denoted by the grades, Super, Prime and Standard. The most important criticism against the previous South African meat grading system is that it was a producer oriented system that did not cater for all sectors in the meat industry.

The carcass grading system was replaced with the South African beef and sheep carcass classification system in 1992, which is still in use. This carcass classification system merely classifies carcasses based on physical and compositional attributes, which include age (age categories $A, A B, B, C$ ), 
carcass fatness (carcass fat codes 1 - 6) and carcass conformation (carcass conformation codes 1 - 5), and damage (1 to 3$)$.

There is a fundamental difference between a carcass grading and a carcass classification system, namely that a classification system is consumer focused because it simply provides categories of carcasses with different physical and compositional qualities, and the choice of carcass depends on the retailer and consumer. This classification system gives no indication of "best quality", but the consumer decides about the "best quality". Meat prices are not fixed, but are based on supply and demand.

\section{Carcass and meat quality}

Carcass and meat quality are complex concepts that are frequently measured using objective indices related to nutritional, microbiological or physiological characteristics (Cardello, 1995). The view that the best measure of meat quality is the consumer's perceptions can be traced to the 1870 s when $\mathrm{H}$. Clark specified that meat quality is an impression that is inappropriate for evaluation by anyone other than the average consumer (Cardello, 1995). Factors influencing perceived meat quality are intrinsic quality cues, convenience, safety and acceptability of sensory characteristics (Schultz \& Wahl, 1981; Umberger et al., 2000).

Certain physical attributes of meat such as meat tenderness can be measured objectively (using instruments) or subjectively (sensory analysis e.g. taste panel). Carcass quality affects meat quality, but the challenge is to categorise carcasses based on physical or anatomical attributes that are easy to measure and relate clearly to preferred meat quality attributes.

In the United States of America (USA), the quality and consistency of livestock production practices were investigated in a series of landmark studies called the National Beef Quality Audit (NBQA). The NBQA of 1991 in the USA demonstrated that American beef contained too much fat, was too tough and too inconsistent to be competitive with pork and poultry in the marketplace. Production and grading systems were revised to improve the overall acceptance of beef carcasses that enter the fabrication section of processing facilities (McKenna et al., 2000). The National Beef Quality Audit of 2000 revealed mean United States Department of Agriculture (USDA) yield grade traits namely mean yield grade (3.0), carcass weight $(356.9 \mathrm{~kg})$, adjusted fat thickness $(1.2 \mathrm{~cm})$ and longissimus muscle area $\left(84.5 \mathrm{~cm}^{2}\right)$, and kidney, pelvic and heart fat (2.4\%).

A recent beef quality audit in South Africa suggests similar trends (Strydom, 2011) to those that were reported in the USA in terms of effective classification and the perceived quality of beef. Studies also suggest that production systems (Frylinck et al., 2013) and production enhancing technologies (Hope-Jones et al., 2010; 2012; Strydom et al., 2011) and abattoir practices such as electrical stimulation of carcasses (Hope-Jones et al. 2010, Strydom et al., 2011) contribute considerably to the variation in carcass and meat quality of beef, despite categorisation into similar classification categories. These observations are important and signal a need to review the current South African carcass classification criteria.

\section{Managing meat quality and safety in South Africa}

Meat safety is controlled by means of the Meat Safety Act, (Act 40 of 2000), which provides guidelines for the conversion of livestock to meat to ensure a safe and wholesome product for consumers. This Act makes provision for the maintenance of quality standards and provides guidelines to ensure carcass and meat hygiene by means of compulsory carcass inspection at all abattoirs, which is not negotiable for any meat or meat products sold to the public.

The Agricultural Product Standards Act (Act 119 of 1990) helps to control and set specific product standards for local and export purposes, based on inspection, grading or classification (Table 1) and sampling for quality control at participating abattoirs.

Table 1 South African Carcass Classification System for cattle and small stock

\begin{tabular}{lcccc}
\hline \multicolumn{5}{c}{ South African Red Meat Classification System } \\
\hline Age category & $\begin{array}{c}\text { A permanent } \\
\text { incisors }\end{array}$ & $\begin{array}{c}1-2 \text { permanent } \\
\text { incisors }\end{array}$ & $\begin{array}{c}3-6 \text { permanent } \\
\text { incisors }\end{array}$ & $\begin{array}{c}\text { >6 permanent } \\
\text { incisors }\end{array}$ \\
\hline Rollermark code & AAA & ABAB & BBB & CCC \\
\hline Colour of rollermark & Purple & Green & Brown & Red \\
\hline \multicolumn{4}{c}{ Carcass fat codes: 0 No fat; 1 very lean; 3 medium; 4 fat; 5 slightly overfat; 6 excessively overfat } \\
\hline \multicolumn{4}{l}{ Conformation scores: 1 very flat to 5 very round } \\
\hline
\end{tabular}


The current process includes a South African beef, lamb and mutton carcass classification system, which describes carcasses based on important physical carcass attributes. These physical attributes are easily evaluated on the carcass and include the age, fat code (subcutaneous fat thickness) and carcass conformation score. Bulls are classified separately. This system provides an effective way of classifying and managing variations in carcass and meat quality, which are indicated by means of distinctive marks and abattoir identification and classification codes depending on the type and size of the abattoir.

\section{Principles of the South African Carcass Classification System}

The age of livestock affects meat quality and especially the tenderness of the meat, which explains why this factor forms the basis of the current South African carcass classification system (Table 1). Animal ageing is generally associated with tougher meat (Dreyer et al., 1977) which is caused by the amount and cross-bridges of connective tissue (collagen and elastin) (Lawrie, 1998). Meat from younger livestock has collagen that is more soluble and immature and consequently more tender. Meat tenderness is generally regarded as the most important attribute of eating quality (Issanchou, 1996; Boleman et al., 1997), and it depends primarily on the content and state of the connective tissue and the structure and state of the myofibrils (Dutson et al., 1976). Meat tenderness is also affected by the meat cut and a range of intrinsic and extrinsic factors associated with the conversion of muscle to meat (Lawrie, 1998).

The emphasis on lean meat production has resulted in a decrease in carcass fat content at slaughter and the production of carcasses with fat codes that range between 2 and 3 for both beef and small stock (Webb \& O'Neill, 2008). Carcass fat contributes to the organoleptic properties of meat by enhancing the juiciness and certain flavour components in meat (Webb \& O'Neill, 2008). The emphasis on lean meat yield and the idea that excess fat is wasteful are probably the main reasons for the significant shift towards the production of carcasses with very specific fat codes. In the past, fatter carcasses were an important way in which producers could increase the dressing percentage, yield and financial value of beef carcasses. However, modern growth enhancing technologies have provided a new and more efficient way of achieving the same goals at lower cost and leaner product (Webb \& Erasmus, 2013).

A critical assessment of the current carcass classification system indicates that there are about 120 combinations of age, fat and conformation classes in which carcasses can be classified. Based on recent data from the Red Meat Abattoir Association, only 5\% - 10\% of the carcass classification system is used effectively, notably classes $A 2, A 3, A B 2, A B 3$, while small proportions of carcasses are classified in other categories. Much of this skewed distribution is due to market forces. It is evident that there is too much variation in just a few carcass classes, while a better description is probably required within these classes. This poses a critical question that the red meat industry will have to address, namely are the current carcass classification categories adequate?

Carcass and resultant meat quality are influenced by a plethora of factors, namely inherent factors such as muscle fibre and connective tissue characteristics and proteolytic enzyme systems, as well as extrinsic factors like breed or type, age, weight, handling, transportation, lairage, nutrition and growth enhancing technologies. There are complex interactions between these intrinsic and extrinsic factors that require careful management. However, it can be predicted that the use of age as a categorisation factor will become less important if age is more similar between animals from different feeding and management systems. It is also clear that certain pre-slaughter handling procedures and abattoir practices contribute to improved meat quality and these are aspects that cannot effectively be described in a classification system. Effective labelling and branding of meat products provide a more logical alternative to guarantee preferred quality which will be the responsibility of specific beef producers or retailers.

\section{Conclusions}

Carcass classification is an essential part of efficient animal production, price determination and meeting consumer demands. Carcass classification differs fundamentally from carcass grading. Carcass classification is the description of carcasses by means of clearly defined characteristics that are of prime importance to the meat industry, retailers and consumers. Extrinsic and intrinsic factors affect carcass and meat quality and the purpose of carcass classification in South Africa, is to classify carcasses to ensure more consistent meat quality, composition and consumer satisfaction.

The conceptual basis of the carcass classification system is the principle that producers, retailers and consumers differ in terms of their perceptions and expectations of carcass and meat quality, and subsequent eating experience. Recent studies in cattle and sheep indicate that the current carcass classification system is used as a grading system and it no longer discriminates effectively between carcasses categorised within the same class, but have different physical and compositional attributes. Research also confirms that the variation within carcass classification categories has increased significantly due to differences between livestock breeds and types, different animal production systems and the use of modern feedstuffs and 
growth enhancing technologies. A comprehensive South African beef and small stock carcass quality audit is recommended.

\section{References}

Agricultural Product Standards Act 119 of 1990: http://uww.nda.agric.za/doaDev/sideMenu/foodSafety/doc/Act\%20119.pdf. (Accessed 5 December. 2014).

Cardello, A.V., 1995. Food quality: Relativity, context and consumer expectations. Food Quality and Preference 6, 163-170.

Boleman, S.J., Boleman, S.L., Miller, R.K., Taylor, J.F., Cross, H.R., Wheeler, T.L., Koohmaraie, M., Shackelford, S.D., Miller, M.F., West, R.L., Johnson, D.D. \& Savell, J.W., 1997. Consumer evaluation of beef of known categories of tenderness. J. Anim. Sci. 75, 1521-1524.

Dreyer, J.H., Naude, R.T., Henning, J.W.N. \& Rossouw, E., 1977. The influence of breed, castration and age on muscle fibre type and diameter in Friesland and Afrikaner cattle. S. Afr. J. Anim. Sci. 7, 171-180.

Dutson, T.R., Hostetler, R.L. \& Carpenter, Z.L., 1976. Effect of collagen levels and sarcomere shortening on muscle tenderness. J. Food Sci. 41, 863-866.

Frylinck, L., Strydom, P.E., Webb, E.C. \& Du Toit, E., 2013. Effect of South African beef production systems on post-mortem muscle energy status and meat quality. Meat Sci. 93, 827-837.

Hope-Jones, M., Strydom, P.E., Frylinck, L. \& Webb, E.C., 2010. The efficiency of electrical stimulation to counteract the negative effects of $\beta$-agonists on meat tenderness of feedlot cattle. Meat Sci. 86, 699-705.

Hope-Jones, M., Strydom, P.E., Frylinck, L. \& Webb, E.C., 2012. Effect of dietary beta-agonist treatment, vitamin D3 supplementation and electrical stimulation of carcasses on colour and drip loss of steaks from feedlot steers. Meat Sci. 90, 607-612.

Issanchou, S., 1996. Consumer expectations of meat and meat product quality. Meat Sci. 43, s5-s19.

Kempster, T., Cuthbertson, A. \& Harrington, G., 1982. Carcass evaluation in livestock breeding, production and marketing, Granada Publishing Ltd., Great Brittan.

Lawrie, R.A., 1998. Lawrie's Meat Science. 6th ed. Woodhead Publishing Ltd. Cambridge, England. 336 pp.

Oliver, M.A., Nute, G.R., Font i Furnols, M., San Julian, M., Campo, M.M., Sanudo, D., Caneque, V., Guerrero, L., Alvarez, I., Diaz, M.T., Branscheid, W., Wicke, M. \& Montossi, F., 2006. Eating quality of beef, from different production systems, assessed by German, Spanish and British consumers, Meat Sci. 74, 435-442.

Schultz, H.G. \& Wahl, O.L., 1981. Criteria for food acceptance. Foster Publishing Ltd., Verlag A.G., Zurich. pp. 90-97.

Umberger, W.J., Feuz, D.M., Calkins, C.R. \& Killinger, K.M., 2000. Consumer preferences and willingness to pay for flavour in beef. International Food and Agribusiness Management Association Meetings, Chicago. 24-25 June, 1-17.

McKenna, D.R., Roebert, D.L., Bates, P.K., Schmidt, T.B., Hale, D.S., Griffin, D.B, Savell, J.W., Brooks, J.C., Morgan, B.J., Montgomery, T.H., Belk, K.E. \& Smith, G.C., 2000. National beef quality audit-2000. Survey of targeted cattle and carcass characteristics related to quality and value of fed steers and heifers. J. Anim. Sci. 2002, 1212-1222.

Meat Safety Act 40 of 2000: www.nda.agric.za/doaDev/sideMenu/APIS/doc/MEATSAFETY.pdf (Accessed 5 December 2014).

Strydom, P.E., 2011. Quality related principles of the South African beef classification system in relation to grading and classification systems of the world, S. Afr. J. Anim. Sci. 41, 177-193.

Strydom, P.E., Hope-Jones, M., Frylinck, L. \& Webb, E.C., 2011. The effects of a beta-agonist treatment, vitamin D3 supplementation and electrical stimulation on meat quality of feedlot steers. Meat Sci. 89, 462-468.

Viljoen, H.F., De Kock, H.L. \& Webb, E.C., 2002. Consumer acceptability of dark, firm and dry (DFD) and normal pH beef steaks. Meat Sci. 61, 181-185.

Webb, E.C., 2013. The ethics of meat production and quality - A South African perspective. S. Afr. J. Anim. Sci. 43, S2-S10.

Webb, E.C. \& Casey, N.H., 1995. Fatty acids in carcass fat of steers treated with a ß-adrenergic agonist feed additive and a trenbolone acetate + oestradiol $-17 ß$ implant. Meat Sci. 41, 69-76

Webb, E.C. \& O'Neill, H.A., 2008. The animal fat paradox and meat quality. Meat Sci. 80, 28-36.

Webb, E.C. \& Casey, N.H., 2010. Physiological limits to growth and the related effects on meat quality. Livest. Sci. 130, 33-40.

Webb, E.C. \& Erasmus, L.J., 2013. The effect of production system and management practices on the quality of meat products from ruminant livestock. S. Afr. J. Anim. Sci. 43, 413-423. 